\title{
EKONOMICKÁ VÝKONNOST A VÝZKUMNÁ AKTIVITA JAKO VÝZNAMNÝ FAKTOR EKONOMICKÉ ODOLNOSTI REGIONš
}

\section{ECONOMIC PERFORMANCE AND RESEARCH ACTIVITY AS AN IMPORTANT FACTOR OF ECONOMIC RESILIENCE OF REGION}

\section{ING. ONDř EJ SVOBODA, PH.D. \\ BC. TEREZA KLEMENTOVÁ}

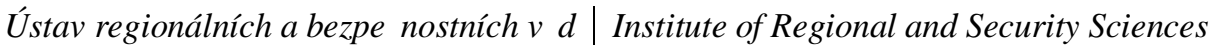 \\ Fakulta ekonomicko-správní Faculty of Economics and Administration \\ Univerzita Pardubice University of Pardubice \\ $\triangle$ Studentská 84, 53210 Pardubice, Czech Republic \\ E-mail: ondrej.svoboda@upce.cz,tereza.klementova@student.upce.cz.
}

\begin{abstract}
Anotace
Pojem ekonomická odolnost region T se v souḷ asné dob门diskutuje pŚdevğm v souvislosti s rostoucí pozorností $k$ ekonomickým krizím, a to zejména $v$ souvislosti se zkoumáním asymetrických regionálních dopad丁 hospodáŚské krize z roku 2008. Cílem !lánku je pomocí analýzy dopadT této krize ovhśit hypotézy vztahujicí se $k d v$ nna potenciálním determinant $\mathrm{T} m$ ekonomické odolnosti regionT: ekonomické výkonnosti a vhlecké aktivit门 regionu. Výzkum je zaloğ́n na analýze 131 regionT úrovn门NUTS 2 vybraných zemí Evropské Unie. Hlavní výzkumnou metodou je korela! ní analýza. Výsledky ukazují, ǵe mezi významné ukazatele vysv Đlující asymetrické dopady hospodáśské krize patŚ produktivita práce, disponibilní dTchod a výdaje na vĐlu a výzkum.
\end{abstract}

\section{Klílová slova}

regionální rozvoj, ekonomická odolnost regionu, hospodáŚská krize, ekonomická výkonnost, výzkumná aktivita

\section{Annotation}

The concept of economic resilience of regions is currently being discussed primarily in the context of increasing attention to the economic crisis, especially in the context of the investigation of asymmetric regional effects of the economic crisis in 2008. Aim of this article is to analyse the effects of the economic crisis of 2008 to verify the hypotheses related to two potential determinants of economic resilience of regions: economic performance and scientific activity of the region. The research is based on an analysis of 131 regions NUTS 2 of the EU countries. The main research method is correlation analysis. The results of the analyses confirm the hypothesis that Labour Productivity, Disposable Income and Expenditures on $R \& D$ are very important determinants.

\section{Key words}

regional development, regional economic resilience, recessionary shocks, economic performance, scientific activity

JEL classification: $R 00$, R10, R11

\section{Úvod}

Odborná veŚejnost, zabývající se ekonomickou odolností regionT, se shoduje v názoru, ǵe má tento výzkum potenciál pŚnést nový pohled na regionální rozvoj pŚ soul asném Śggení mnohých nejistot a 
zmhn ve spolel nosti. Pojem odolnost regionT se objevuje nejen v odborné literatuŚ zabývající se klasickými faktory regionálního rozvoje, ale lze jej dohledat i ve studiích zkoumajících reakci regionT, jeǵ jsou vystaveny dopadTm pŚrodních i antropogenních mimoŚidných událostí znal ného rozsahu. NapŚklad je moǵné jej nalézt jak v oblasti výzkumu spadajícího do krizového plánování zejména ve spojitosti se zkoumáním dopadT selhání kritické infrastruktury, tak i v oblasti výzkumu zamßśjícího se na schopnost regionT zotavit se po rozsáhlých povodních (podrobnクi viz Pelling, 2011; Rose a Liao, 2005).

Odolnost je v g̈rğm smyslu chápána jako schopnost socioekonomického systému existujícího ve vymezeném regionu odolat a následnク se úsphọn adaptovat na vychýlení ze své dosavadní rovnováhy. Rovnováhou je v tomto smyslu pojímán ǵádoucí stav sledovaných veli!̣ in, který umoǵRuje efektivní rozvoj regionu. Ekonomická odolnost regionu je pak nahlíǵena jako schopnost ekonomik regionT reagovat vhodným zp丁sobem na existenci vlivu mnoǵiny událostí pŚrodního !̣i antropogenního p丁vodu majících schopnost vychýlit ekonomiku regionu z ustáleného stavu. Lze tedy konstatovat, ǵe pojem regionální odolnost v sobクskrývá schopnost regionu efektivnクodolávat rTzným výzvám (jak náhlým výkyvTm, tak i pomalu bhớcím neǵádoucím jevTm).

Vyugoitelnost pojmu zkoumala jiǵ Śda regionálních analytikT (srov. napŚ Foster, 2007; Hill a kol., 2011; Vogel, 2007). NapŚklad Pendall a kol. uvádí, ǵe (Pendall a kol., 2010): Ăzkoumání regionální odolnosti umoğ́́ije odhalení potenciálních rizik rozvoje regionT zahrnujících jak pŚrodní a ekonomické otŚsy, tak i pomalu pJsobící a dlouhotrvající procesy, jeǵ mají charakter bariér dalğho rozvoje.ñ Mezi tyto procesy Śdí napŚklad dlouhodobou deindustrializaci regionu, vylidŔování území, demografické zmhyy (napŚ stárnutí populace) !̣i klimatické zmßny atd. Regionální odolnost je tak

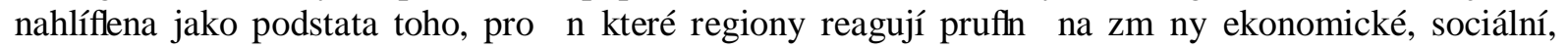
politické ! i ekologické, zatímco jiné dlouhodobĐzaznamenávají zhorg̉ení svého dosavadního rozvoje.

Z výğe uvedeného lze soudit, ğe zkoumání regionální odolnosti mTǵe zlepğt porozumhí rizikTm, která je nutné zohlednit v rámci strategického managementu regionT. Ekonomická odolnost je l asto zmiŔována ve vztahu k otevŚ́nosti ekonomik. V tomto ohledu uvádí nhkteŚ autoŚ (napŚklad Kraft a kol., 2011; Koutský a kol., 2012), ǵ́ propojení ekonomik nepŚnáğ jen pozitiva, ale také zvýǵenou citlivost regionT na rTzné hospodáŚsé výkyvy. Vysoká otevSenost ekonomik ï a z toho vyplývající vzájemná závislost regionTï je v okamğicích hospodáŚsých problémT pŚ| inou zvýǵené náchylnosti ekonomik vȚi poklesTm. Z dTvodu rostoucí otevŚnosti ekonomik roste potŚeba systémového a celistvého pŚstupu, který si klade za cíl vysvnlit pŚ|iny rozdílných dopadT rTzných exogenních výkyv丁 na ekonomiky regionT.

\section{Ekonomická odolnost regionu a moǵnosti jejîho mršení}

Walker a kol. povaǵují za základní vymezení pojmu odolnost (Walker a kol., 2010): Ăschopnost systému odolat ġku, vyrovnat se se zmhnou a nadále prospívat.ñ Podobnou definici uvádí Fosterová, která definuje regionální odolnost jako (Foster, 2007): Aschopnost regionu zotavit se z významné zm円hy.ñ Za zdroj Ăzmßnyñ která ohroǵuje rozvoj regionu, je moǵné povaǵovat jak událost mající charakter mimoŚdné události velkého rozsahu (ḷ asto ǵvelního charakteru), tak i významné celonárodní nebo nadnárodní recese. Definici ekonomické odolnosti regionu vymezuje napŚklad Hill a kol., kteŚ ji vnímají jako (Hill a kol., 2011): Ăschopnost ekonomiky regionu zotavit se úsphỏn z vychýlení, jeǵ mクı negativní dopad na dosavadní vývoj regionuñ Zde je nutné zdTraznit, ǵe zdroj Ǎvychýleníñje vnímán exogenn円ï ! ili pochází z vnクğho okolí regionu.

V ḷ eské odborné literatuŚ se problematikou regionální odolnosti zabýval napŚ Koutský a kol. (Koutský a kol., 2012) nebo Kraft a kol. (Kraft a kol., 2011). Koutský a kol. (Koutský a kol., 2012) pojímá ekonomickou odolnost regionu jako Ăschopnost regionální ekonomiky reagovat na zmhnu podmínek (i gókové povahy) a nacházet nové rovnováğ́é stavyñ $V$ nhterých pŚpadech je odolnost regionT nazírána nikoli jako vlastnost, ale spíg jako proces, v jehoǵ rámci dovedou regiony vhodnク ! elit nepŚznivým okolnostem (napŚ Koutský a kol., 2012). 
Lastým tématem pŚ výzkumu ekonomické odolnosti regionT je identifikace faktorT, které mají potenciál ovlivŔovat ekonomickou odolnost regionT (dále jen EOR). Martin uvádí, ǵe nalezení a prokázání vlivu faktorTEOR ! asto naráği na to, ğe je obtíǵné identifikovat ty, které by byly spolehlivé napŚ! odlignńmi regiony (Martin, 2012).

Rozdílnost dopadT hospodáŚsých výkyvT je ovlivn円ha schopností adaptace, kterou mají podniky i pracující síla v regionu. V pŚpadク firem se jedná o to, jak snadno jsou schopny pŚ́jít $k$ jiným

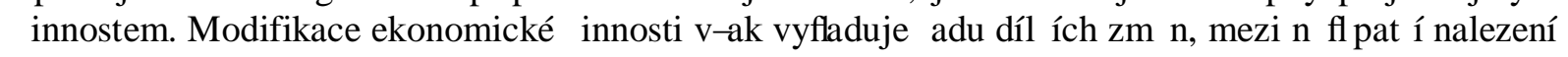
nových odbytových trhT, zajiğnní nových výrobních vstupT, zavedení nových technologií atd.

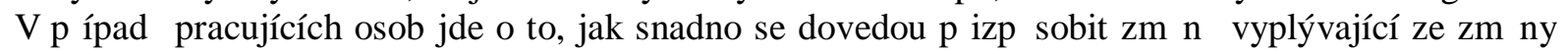
pracovní !̣innosti. Pokud vyjdeme z uvedeného pohledu, pak mTǵeme Ści, ǵe region mTǵe být relativnクvíce odolný pouze $\mathrm{v}$ nhterých ohledech (napŚ ve vztahu $\mathrm{k}$ podnikTm), ale $\mathrm{v}$ jiných ohledech mTǵe vykazovat odolnost relativnクmenğ (napŚ pokud se jedná o trh práce).

Al koli je stanovení moğných determinantT regionální ekonomické odolnosti obtíǵné, lze uvést nhkolik moǵných souvislostí, které pŚcházejí v úvahu. Z hlediska determinantTEOR je moǵné pŚedpokládat, ǵe regiony mající nadprTmß̧nou produktivitu, vysokou úroveḱ produktu, které mají soul asnクvysokou

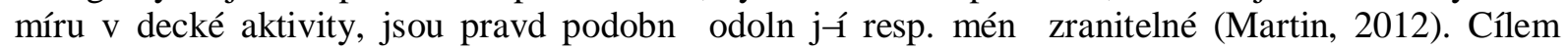
pŚspßłku je pŚsph k ovłśní vlivu výǵe uvedených determinantT, které lze shrnout pod dva potenciální faktory: ekonomická výkonnost a výzkumná aktivita regionu. Vzájemná souvislost uvedených faktorT je ! astým tématem rTzných výzkumT (napŚ Kraftová a kol., 2013).

Pro dosaǵení uvedeného cíle je nutné zvolit vhodný zpTsob kvantifikace ekonomické odolnosti regionT. V odborné literatuŚ se lze dále setkat s Śdou ukazatelT, které jsou doporul ovány pro kvantifikaci ekonomické odolnosti regionT. Mezi moǵné ukazatele ekonomické odolnosti regionT lze zaŚdit napŚklad (ESPON, 2012), (Martin, 2011):

- pol et pracujících osob a míru zamß̧tnanosti regionu,

- zamßstnanost podle odv hví a míru ekonomické aktivity,

- hrubou pŚdanou hodnotu a produktivitu práce,

- pol et podnikT v regionu a pol et podnikT v exportních odvhvích,

- velikost mezd a investic.

Vhğnou se vğkk za dostatel ný základ pro kvantifikaci ekonomické odolnosti regionT povaǵuje buṆ regionální produkt, nebo regionální úroveŔ zam\$tnanosti. Vzhledem k problematil nosti stanovení regionálního produktu je !̣asto sledován vývoj regionální zamß̧tnanosti (Martin, 2011). Oproti regionálnímu produktu má jak své výhody, tak i nevýhody. Jako nevýhodu lze vnímat pśdevğm to, ǵe v sobクabsentuje údaj ohlednクvelikosti produktivity práce. Spolel nou nevýhodou obou ukazatelT je nemoǵnost odstínクní vlivu dojíǵdnií za prací.

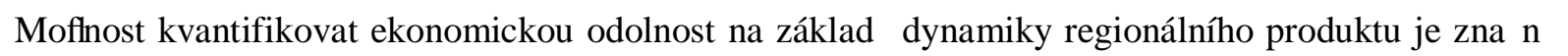
omezena tím, ǵe zveŚjiḱování thchto údaj丁 podléhá napŚklad u subnárodních regionT EU relativnク

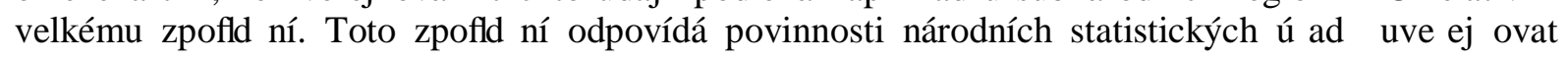
regionální HDP na úrovni NUTS 2 do 2 let od konce sledovaného období.

Výhodou ukazatele regionální zam ḩtnanosti je jeho sociální rozmク v reakci regionu na hospodáŚký výkyv. Lze totiǵ konstatovat, ǵe prudce klesající úroveŔzamßşnanosti mTǵe být v dTsledku p丁sobení negativního hospodáśského výkyvu vnímána obyvateli jako citelný znak ekonomické neodolnosti

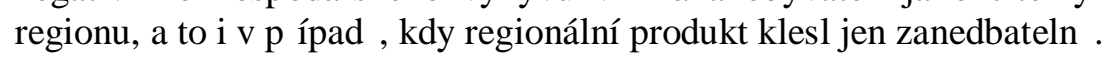

Jako pŚklad výzkumu ekonomické odolnosti regionT zaloğeného na zkoumání reakce regionT z hlediska úrovnクzam \$̧tnanosti lze uvést studii anglického ekonomického geografa Martina Rona (Martin, 2011). Ten se zamf́́l na analýzu dopadT hospodáśsých poklesT zkoumaných

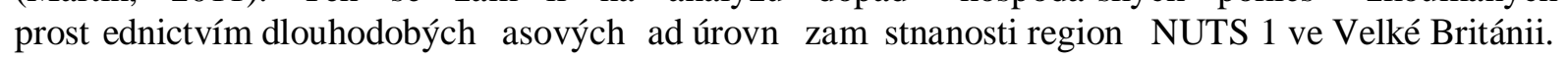




\section{Metodika výzkumu}

Cílem výzkumu je ovhśení významu dvou potenciálních determinantT EOR: vliv ekonomické výkonnosti regionu a vflecké aktivity na ekonomickou odolnost regionu. Z výǵe uvedených dTvodT byla ekonomická odolnost kvantifikována na !̣ asových Śdách poḷ tu pracujících osob v regionech zaŚzzených do výzkumného vzorku. Konkrétnク byly zkoumány dopady hospodáŚsé krize z roku 2008, a to na 131 regionech úrovnநNUTS 2 devíti zemí EU (Rakousko, Leská republika, Nクnecko, Ġanךsko, Francie, Itálie, Polsko, Slovensko, Velká Británie). Z mnoǵiny vğech regionT thłhto stát T byly vybrány ty, u kterých bylo moǵné identifikovat body zlomu (body zlomu oddクují rostoucí a klesající !̣ásti ḷasové Śidy poḷ tu pracujících osob v regionu) a soul asnク u nich dog̉o vlivem hospodáŚské krize k prokazatelnému poklesu odhadovaného reálného regionálního produktu (odhad byl uskute! nhy pomocí implicitního cenového deflátoru získaného z databáze UNSTAT (UNSTAT, 2013)). Celkem tak vstupovalo do výzkumu 175 regionT a po uvedené selekci bylo zaŚszeno do dalğ analýzy pouze 131 regionT (pŚ| emǵ byly zastoupeny regiony ze vg̉ech uvedených státTEU).

Pro úl ely výzkumu byly stanoveny 2 hypotézy:

H1: ÄEkonomická výkonnost regionT je významným faktorem ekonomické odolnosti regionT.ñ

H2. ĂVýzkumná aktivita regionT je významným faktorem ekonomické odolnosti regionT.ñ

Pro ovhśéní platnosti hypotézy je nutné prokázat statisticky významný vztah mezi ukazateli zastupujícími ekonomickou výkonnost regionu resp. vhleckou aktivitu regionu (viz tabulka !. . 1 a !. . 2) s níǵe popsanými ukazateli EOR. Fáze poklesu a fáze oğivení byla u zkoumaných regionT identifikována na !̣t tvrtletních ! asových Śidách poḷ tu pracujících osob zkoumaných regionT. Zdrojem dat tḩhto ḷ asových Śid bylo výbłgové getśení pracovních sil (LABOUR FOURCE SURVEY, 2013).

Ekonomická odolnost regionT byla zkoumána v období 1. | tvrtletí roku 2008 aǵ3. | tvrtletí 2012. Pro úl ely výzkumu byla zkoumaným faktorTm pśśszena sada ukazatelT (viz tabulka !. 1 a ! . 2). Údaje o regionech odpovídající v tabulkách uvedeným ukazatelTm byly získány z databáze EUROSTATu (EUROSTAT, 2012) za roky 2006 a 2007. Dvクsady dat za uvedené roky reprezentují moǵné zpoǵdநní pTsobení determinant T na EOR (2 leté zpoǵdhí p丁sobení odpovídá pouğití datových sad z roku 2006, 1 leté zpoǵdní odpovídá roku 2007). Uvedené dva roky je moğné povaǵovat za poslední roky, kdy ekonomiky zkoumaných regionT nebyly jeġクovlivnhy dopadem hospodáśké krize z roku 2008 a proto je moǵné je vyuğít pro analýzu determinantTEOR.

Pro úl ely ovhśení hypotéz byly pouǵity následující ukazatele kvantifikující EOR: velikost obnovení poḷ tu pracujících osob regionu mhśená mezi 1. !ٕ tvrtletím 2008 a 3. ! tvrtletím 2012 pom円em pol tu pracujících osob v uvedených okamǵicích (symbol VO). Dalğ ukazatelem EOR byla zmßna poḷtu pracujících osob v první fázi poklesu (rychlost poklesu, symbol F1) a v první fázi oğivení (rychlost oğivení, R1).

Pro ovfא́ení hypotéz byla provedena korela! ní analýza (pro hladinu významnosti 0.05) mezi ukazateli zastupující faktor ekonomické výkonnosti a vhlecké aktivity a výǵe uvedenými ukazateli EOR (F1, $\mathrm{R} 1, \mathrm{VO})$. Z dTvodu nepr Tkaznosti normálního rozdクení vstupních dat byla pouğita neparametrická varianta korela!̣ ní analýzy ï výpoḷ et Spearmanova koeficientu korelace. Detailní zpJsob úpravy vğech pouǵitých datových sad byl popsán v pŚedeg̉ém výzkumu (viz Svoboda, 2014).

\section{Výsledky výzkumu}

Výsledky korela!̣ ní analýzy ukazující vliv jak faktoru ekonomické odolnosti, tak i vhlecké aktivity regionu shrnuje text této podkapitoly. Níge jsou popsány výsledky, které jsou podstatné pro ov hśení stanovených hypotéz. 
Tab. 1: Výsledky korela!̣ní analýzy - Ekonomická výkonnost regionu (st. významné hodnoty tu!̣nり

\begin{tabular}{|c|c|c|c|c|c|c|}
\hline \multirow{2}{*}{ Prom円nná / Rok } & \multicolumn{3}{|c|}{2007} & \multicolumn{3}{|c|}{2006} \\
\hline & F1 & R1 & $\mathrm{VO}$ & F1 & R1 & VO \\
\hline $\begin{array}{l}\text { Hrubý domácí produkt v błğ́ných tróních cenách na obyvatele } \\
\text { (v PPS) }\end{array}$ & $-0,402$ & 0,088 & 0,418 & $-0,395$ & 0,087 & $\mathbf{0 , 4 3 3}$ \\
\hline Tvorba hrubého fixního kapitálu na obyvatele & $-0,242$ & $-0,125$ & $-0,029$ & 0,200 & $-0,084$ & $-0,402$ \\
\hline Produktivita práce (HPH na pol et pracujících osob) & $-0,446$ & 0,121 & $\mathbf{0 , 5 7 3}$ & $-0,063$ & $\mathbf{0 , 4 5 0}$ & $\mathbf{0 , 3 6 3}$ \\
\hline Disponibilní dTchod na obyvatele & $-0,356$ & $\mathbf{0 , 3 0 2}$ & 0,535 & $-0,244$ & 0,303 & 0,467 \\
\hline
\end{tabular}

Výğe uvedená tabulka (tabulka !. 1) zobrazuje výsledky korela!̣ ní analýzy pro ukazatele, které lze pŚŚdit k faktoru Ăekonomická výkonnost regionuñ Výsledky ukazují na to, ǵe vğechny zvolené ukazatele je moǵné povaǵovat za statisticky významné determinanty EOR (kaǵdý z ukazatelT zastupujících ekonomickou výkonnost regionu statisticky významnり koreluje s alespoŔ jedním ukazatele EOR (F1, R1 a VO) ï viz tu!̣nĐzvýrazn円̧é hodnoty.

Ukazatel ĂTvorba hrubého fixního kapitálu na obyvateleñ prokázal statisticky významný vztah s ukazatelem VO pouze pro hodnoty roku 2006. Druhý ukazatel, který prokázal citlivost na velikost zvoleného zpoǵdnií p丁sobení determinantT, byl ukazatel ĂProduktivita práceñ Tento ukazatel prokázal statisticky významný vztah s ukazatelem EOR ve fázi rTstu (R1) pouze pro hodnoty roku 2006.

Z hlediska velikosti míry tḩ̧nosti korela! ního vztahu je moǵné uvést jako jeden z významných vztahT vliv ukazatele ĂDisponibilní dTchod na obyvateleñna ukazatel VO (korela!̣ ní koeficient 0,535 pro rok 2007 a 0,467 pro rok 2006). Tento ukazatel také koreluje statisticky významnクs ukazatelem F1 a R1. Vzhledem k tomu, ǵe se v prvním pŚpadh(s F1) jedná o negativní korelaci a v druhém pŚpad円(s R1) se jedná o pozitivní korelaci, je moǵné usuzovat na to, ǵe velikost disponibilního dTchodu na obyvatele sniǵuje rychlost propoug்hí ve fázi poklesu a naopak zvyg்ije rychlost zvyǵování poḷ tu pracujících osob ve fázi oğivení.

Dalğm významným determinantem byl potvrzen ukazatel Produktivita práce (vyjádŚnna jako HPH na poḷ et pracujících osob) a ukazatel HDP (vyjádŚen v jednotkách standardu kupní síly). První uvedený ukazatel koreluje statisticky významnクs ukazatelem VO (koeficient korelace je 0.573 pro hodnoty $\mathrm{z}$ roku 2007 a 0,363 pro hodnoty $\mathrm{z}$ roku 2006). To potvrzuje domn円hku, ǵe regiony s vyğg produktivitou práce mají vhğ schopnost regenerace po hospodáśsém poklesu vzhledem k poḷtu pracujících osob ve srovnání s regiony ménク produktivními. Druhý ukazatel (HDP) koreluje statisticky významnクs ukazatelem VO (koeficient korelace je 0.418 pro hodnoty z roku 2007 a 0,433 pro hodnoty z roku 2006). To lze také interpretovat tak, ǵe v/ğg schopnost regenerace poḷtu pracujících osob mají regiony s vyğǵm HDP. Ukazatel HDP navíc koreluje negativnךs ukazatelem F1 jak pro data $\mathrm{z}$ roku 2006 tak i pro 2007. Jelikoǵ ukazatel F1 vyjadŚ́je rychlost poklesu poḷtu pracujících osob v regionu, lze ukazatel HDP povaǵovat za významnou charakteristiku regionu, která sniǵuje rychlost propoug̉hí. Stejnク tak lze za významný ukazatel z hlediska EOR uvést ĂTvorbu hrubého fixního kapitálu na obyvateleñ Shrneme-li uvedená zjiğhní, je moğné prohlásit první hypotézu za ovfśénou.

Tabulka ! . 2 uvádí výsledky korela! ní analýzy pro oblast Ăvýzkumná aktivita regionuñ Na základク celkového posouzení statisticky významných vztahT je moǵné uvést, ğe se rozdílnost zpoğdhní pTsobení faktorT EOR potvrdila pouze v pŚpadク ukazatelT: ĂPodíl pracujících osob ve VaV na ekonomicky aktivním obyvatelstvuñ a ĂPodíl výzkumníkT ve VaV na ekonomicky aktivním obyvatelstvuñ Oba ukazatele prokázaly statisticky významný korela! ní vztah s ukazatelem VO jen pro zpoǵdní o délce jednoho roku (pro hodnoty 2007). Ostatní nalezené vztahy je moǵné povaǵovat s ohledem na velikost zpoǵdhní za srovnatelné.

Nejsilnクg் statisticky významný vztah prokázal ukazatel ĂPol et patentových pŚhláğek na milion obyvatelñ který statisticky významnクkoreloval s ukazatelem VO jak na základクhodnot z roku 2007 
(korela!̣í koeficient je 0,599), tak i pro rok 2006 (korelal ní koeficient je 0,617). Lze tedy konstatovat, ǵ́ výzkumná aktivita regionu mßśená poḷ tem patentových pŚhláǵek pozitivnクovlivŔuje schopnost regionu odolávat a regenerovat se z hospodáśského poklesu. Vǵechny dalğ zkoumané ukazatele je také moǵné povaǵovat za významné ukazatele z hlediska EOR. Za univerzální ochranný faktor je moǵné oznal it právク ukazatel ÂPol et patentových pŚhláġek na milion obyvatelñ jelikoǵ statisticky významnクkoreloval jak s ukazatelem zmhy pol tu pracujících osob ve fázi poklesu (F1), ale i ve fázi oğivení (R1). Na základクuvedených zjiğhí je moǵné konstatovat, ǵe i druhou hypotézu je moǵné povaǵovat za potvrzenou.

Tab. 2: Výsledky korela!̣i analýzy - Výzkumná aktivita regionu (stat. významné hodnoty tu!̣nり

\begin{tabular}{|l|c|c|c|c|c|c|}
\hline \multirow{2}{*}{ Prom ņná / Rok } & \multicolumn{3}{|c|}{2007} & \multicolumn{3}{|c|}{2006} \\
\cline { 2 - 7 } & F1 & R1 & VO & F1 & R1 & VO \\
\hline Celkové vnitropodnikové výdaje na VaV (v PPS) & $\mathbf{- 0 , 4 7 0}$ & 0,105 & $\mathbf{0 , 4 7 7}$ & $\mathbf{- 0 , 5 3 4}$ & 0,005 & $\mathbf{0 , 4 1 8}$ \\
\hline $\begin{array}{l}\text { Podíl pracujících osob ve VaV na ekonomicky aktivním } \\
\text { obyvatelstvu }\end{array}$ & $\mathbf{- 0 , 4 2 6}$ & $-0,034$ & $\mathbf{0 , 3 5 9}$ & $\mathbf{- 0 , 4 3 4}$ & $-0,201$ & 0,001 \\
\hline $\begin{array}{l}\text { Podíl výzkumníkT ve VaV na ekonomicky aktivním } \\
\text { obyvatelstvu }\end{array}$ & $\mathbf{- 0 , 3 3 2}$ & 0,120 & $\mathbf{0 , 3 6 1}$ & $\mathbf{- 0 , 3 6 9}$ & $-0,039$ & $-0,001$ \\
\hline Pol et patentových pŚhláǵk na mil. Obyvatel & $\mathbf{- 0 , 4 3 7}$ & $\mathbf{0 , 3 1 4}$ & $\mathbf{0 , 5 9 9}$ & $\mathbf{- 0 , 4 2 3}$ & $\mathbf{0 , 3 3 7}$ & $\mathbf{0 , 6 1 7}$ \\
\hline \multicolumn{1}{|c|}{ Zdroj: Vlastní zpracování dle LABOUR FOURCE SURVEY a EUROSTAT } \\
\hline
\end{tabular}

\section{Závf}

PŚspłyek stru! nク pojednává o pojmu ekonomická odolnost regionT a pŚdstavuje moǵnosti jeho młśení. Cílem pŚsphłku je ovłśení dvou hypotéz o vztahu dvou potenciálních faktorT (ekonomické výkonnosti a vĐlecké aktivitクregion]) k ekonomické odolnosti regionu. Výsledky korela! ní analýzy ukazují souvislost Śidy ukazatelT, které lze povaǵovat za ukazatele faktoru ekonomické výkonnosti resp. i faktoru v hlecké aktivity regionu, s ekonomickou odolností regionT mhśnou reakcí regionT na hospodáŚskou krizi v roce 2008 prostŚednictvím vývoje pol tu pracujících osob. Korela! ní analýzou

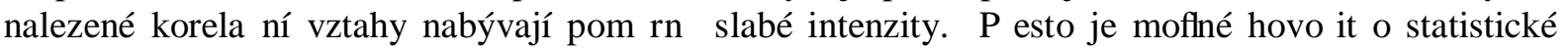

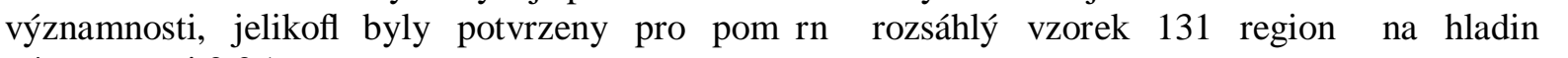
významnosti 0.05 .

\section{Literatura}

[1] ESPON., (2012). Economic Crisis: Resilience of Regions. [online]. [cit. 2012-08-19]. ESPON \& Cardiff University Dostupné Z: <http://www.espon.eu/export/sites/default/Documents/ Projects/AppliedResearch/ECR2/ECR2_inception_report.pdf $>$.

[2] Eurostat. General and regional statistics. [online]. [cit. 2012-10-15]. Dostupné z: <http://epp.eurostat.ec.europa.eu/portal/page/portal/statistics/search_database>.

[3] HILL, E., ST. CLAIR, T., et al., (2011). Economic shocks and regional economic resilience. Working Paper 2011-13, Building Resilient Regions. Institute of Governmental Studies, University of California, Berkeley.

[4] FOSTER, K. A., (2007). A case study approach to understanding regional resilience. Working Paper 2007-08. Berkeley: Institution of Urban and Regional Development.

[5] KOUTSKÝ, J., RUMPEL, P., SLACH, O. a kol., (2012). Profilace $m$ ḩkkých faktorT regionálního rozvoje jako nástroj posilování regionální odolnosti a adaptability. Certifikovaná metodika Ministerstva pro místní rozvoj. [online]. [cit. 2012-9-09] Dostupné z: <http://zam.uur.cz/Rohrerova/Certifikovanemetodiky/10-Koutsky-WD-61-07-1.pdf>.

[6] KRAFT, J. a kol., (2011). Východiska z krize. Cesty zmírnПuí negativních efekt T hospodáŚské krize $v$ L $R$. Liberec: Technická univerzita v Liberci. ISBN 978-80-7372-787-1.

[7] KRAFTOVÁ, I., MAT'NA, Z., ZDRAG̣L, P., (2013). Innovation Industry Drivers. In Proceedings of the 11th International Conference Liberec Economic Forum 2013. pp. 329-328. [online]. [cit. 2014-10-04]. Dostupné z: < http://www.lef-tul.cz/sekce/LEF_2013.pdf>.

[8] LABOUR FOURCE SURVEY, (2013). [online]. [cit. 2013-04-21]. Dostupné z: <http://www.czso.cz/csu/redakce.nsf/i/zam_vsps>.

[9] MARTIN, R., (2012). Regional economic resilience, hysteresis and recessionary shocks. Journal of Economic Geography, vol. 12, iss. 1, pp. 1 ï 32. DOI 10.1093/jeg/lbr019. 
[10] MARTIN, R., GARRETSEN H., FINGLETON, B., (2012). Recessionary Shocks and Regional Employment: Evidence on the Resilience of U. K. Regions. Journal of Regional Science, vol. 52, iss. 1, pp. 109ї 133. DOI 10.1111/j.1467-9787.2011.00755.x.

[11] PELling, M., (2011). Adaptation to Climate Change. From Resilience to Transformation. London: Routledge.

[12] PENDALL, R., FOSTER, K. A., a kol., (2010). Resilience and regions: building understanding of the metaphor. Cambridge Journal of Regions, Economy and Society, vol. 3, iss. 1, pp. 59 - 70. DOI 10.1093/cjres/rsp028.

[13] ROSE, A., LIAO, S.Y., (2005). Modelling regional economic resilience to disasters: a computable general equilibrium model of water service disruptions. Journal of Regional Science, vol. 45, iss. 1, pp. 75 ï 112. DOI 10.1111/j.0022-4146.2005.00365.x.

[14] SVOBODA, O., (2014). Vliv lidského kapitálu na ekonomickou odolnost regionT. In Mezinárodní vฤlecká konference Hradecké ekonomické dny 2014 ï Ekonomický rozvoj a management regionT. Hradec Králové: Gaudeamus. pp. 457-263. ISBN 978-80-7435-366-6.

[15] SVOBODA, O., MAĞÁLKA, M., (2013). The resilience of Czech regions to economic crisis. 16th International Colloquium on Regional Sciences. Conference Proceedings. Brno: Masarykova univerzita. pp. 487-493. ISBN 978-80-210-6257-3. DOI 10.5817/CZ.MUNI.P210-6257-2013-61.

[16] VOGEL C. et al., (2007). Linking vulnerability, adaptation, and resilience science to practice: Pathways, players, and partnerships. In Global Environmental Change. pp. 349-364 [online]. [cit. 2012-09-15] Dostupné $\quad \mathrm{z}$ : <http://fs.wa4.lucklaboratories.com/knowledgebase/wikiadapt/images/8/8e/Linking_vulnerability,_adaptation,_and_resilience_science_to_practice.pdf $>$.

[17] WALKER, B., CARPENTER, S., a kol., (2010). Resilience Management in Social-ecological Systems: a Working Hypothesis for a Participatory Approach. In Conservation Ecology. [online]. [cit. 2012-10-02]. Dostupné z:<http://www.ecologyandsociety.org/vol6/iss1/art14/>.

[18] UNSTAT., (2013). Implicit Price Deflator [online]. [cit. 2013-08-11]. Dostupné z: $<$ http://unstats.un.org/unsd/snaama/dnllist.asp>.

PŚspゆek byl zpracován v rámci projektu !. SGSFES-2014002 IGA Univerzity Pardubice. 